\title{
Monetary implications of the crisis: Dominance at stake*
}

\section{Charles Wyplosz**}

\section{Summary}

The paper asks whether the financial crisis is upsetting the struggle for dominance between monetary and fiscal policy. It argues that a crisis is indeed a key moment when challenges to monetary policy dominance are greatest. However, the need to bail out financial institutions blurs the distinction between monetary and fiscal policy. The subsequent shift to public debt stress further weighs on central banks. The paper also discusses the situation when the interest rate hits the zero lower bound.

Keywords: Policy dominance; monetary policy; fiscal policy; European integration

JEL Classification Numbers: E42, E43, E44, E63

* I am indebted to Torben Andersen and Steinar Holden for very useful comments and suggestions and to comments from participants at the Conference on the Fiscal Consequences of the Crisis organized by the Nordic Economic Policy Review in Copenhagen on March 22, 2010.

${ }^{* *}$ Graduate Institute, Geneva and CEPR. 
The potential for conflict between the monetary and fiscal authorities is well established since, at least, Sargent and Wallace (1981). Canzoneri et al. (2001) have formalized this conflict over who determines the price level as a question of dominance.

The issue arises when looking at the single, consolidated public sector budget constraint, where the public sector includes both the general (central and local) government and the central bank. For the public sector to be solvent, current and future revenues must match current and future spending, including inherited debt service. The question is who is ultimately doing the job of satisfying the single constraint? There are three classes of answer. One solution is that the constraint is not satisfied; then the public sector is insolvent, it must default on its debt and the constraint defines the amount of debt that is serviceable. Another solution is that eventually the central bank will be "convinced" to "print money", allowing the government to carry on with its spending and revenue choices. This is the case of fiscal policy dominance. Monetary policy dominance, the last solution, occurs when the central bank will not be responsible for public spending sector solvency. In that case, it is the government branch that will have to change its spending and revenue decisions to bring them in line with the constraint. Crucially, which solution will prevail is never known for sure since the constraint involves both current and future revenues, as far back into the future as we want to see. The resolution of the dominance conflict can only be based on expectations, and expectations can change.

In many ways, this theory has contributed to independence being granted to central banks in a large number of countries. The intent was, and remains, to achieve monetary policy dominance. The fundamental reason is that independent central banks are better protected from the inflation temptation than are governments because the latter face elections.

Following Grilli et al. (1991) and Cukierman et al. (1992), a large literature has confirmed and qualified the general presumption that central bank independence leads to lower inflation at no cost to economic growth. This has led to an emphasis on the role of institutions and the associated link with the exchange rate regime. It came to be recognized that true central bank independence may be difficult to achieve in some countries, and that an exchange rate anchor could be a substitute (Ghosh et al., 2000). The anchor, however, would have to be of the hard variety: a currency board, dollarization or monetary union. This in turn led to the bipolar view (Eichengreen, 
1994; Fischer, 2001), according to which the only stable exchange rate regimes are either those that let the exchange rate float freely or hard pegs. The Washington Consensus went on to advocate full capital mobility with free floats combined with strong central bank independence and, failing that, hard pegs.

The great financial crisis is reopening this debate. The massive increase in public debts of the last two years started as a blessing - governments were bravely and appropriately acting against the threat of a deep and long-lasting regression - but is bound to turn into a quagmire. Several years of deep deficits have boosted public debts. Most policy measures were designed to be temporary in nature. Indeed a large part of the deficits reflected the automatic stabilizers, and will disappear once growth resumes. Yet, the budgets will not return to balance automatically. The size of the effort to stabilize first, and then reverse the debt build-up, is not trivial; sustainability is thus becoming an issue in some cases. The present paper examines the implications of this situation for monetary policy, viewed from the prism of fiscal vs. monetary policy dominance. Could the pendulum swing back towards fiscal policy dominance as governments face challenging times?

To set the stage, the next section briefly quantifies the deficit slippage. Section 2 examines the various battlegrounds for the struggle over dominance. The implications for monetary policy are drawn in section 3 . The last section concludes.

\section{Graphical arithmetic of budget deficits ${ }^{1}$}

The fiscal effort that will be required in the coming years depends on a host of conditions and assumptions that lead to various estimates. In order to keep things transparent, this section presents simple back-of-the-envelope calculations that should provide an idea of the size of the problem. Public debts are currently estimated to rise by some 30 percent of GDP, often more. Assuming that the difference between the interest rate and growth is 2 percent, this implies that the budget balance must improve by 0.6 percent of GDP to

\footnotetext{
${ }^{1}$ For a recent analysis that yields similar conclusions, see IMF (2009).
} 
make up and prevent a destabilization of the debt. ${ }^{2}$ Bringing the debt back down to where it started is more challenging. In principle, this should be spread over time since, from the fiscal policy perspective, the debt build-up can be seen as an unexpected shock. Figure 1 considers two cases, when the reduction is achieved over just 10 years and when it is achieved over 25 years, an ambitious goal already. Depending on the debt level reached, the budget must be brought to a permanent surplus ranging from 2 percent to 6 percent of GDP.

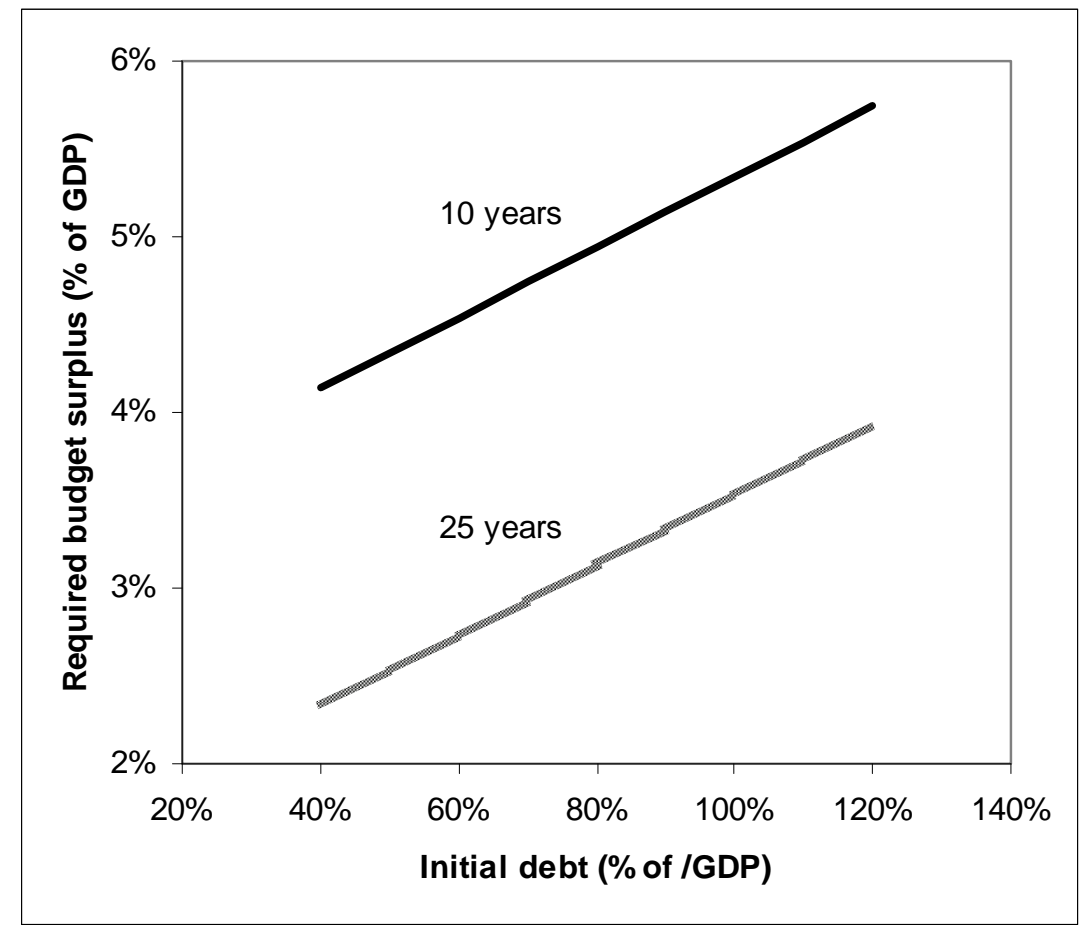

Figure 1. Budget surplus required to reduce the debt by 30 percent of GDP Source: Author's calculation, see Appendix.

That is not all, however. There is some debate on whether growth rates will be durably reduced once the crisis is over, but no one is apparently arguing that GDPs will go back to their pre-crisis trends, at least in the developed

\footnotetext{
${ }^{2}$ Denote the debt-to-GDP ratio as $b$, the budget surplus as a ratio to GDP as $s, r$ as the real interest rate and $g$ as the real growth rate. The debt-stabilizing surplus is $s=(r-g) b$. The calculation looks at the change in this relationship, i.e. $\Delta s=(r-g) \Delta b$., assuming that $r-g=2$ percent.
} 
countries. The baseline case, therefore, describes the recovery and the subsequent years as in the left-hand chart in Figure 2. The right-hand chart describes the second assumption under the baseline case scenario: that, after a temporary increase in outlays - for example on unemployment benefits and various subsidies, public spending resumes its previous trend while tax revenues are tied to GDP and follow a similar path as GDP. The implication is simple. The budget - assumed to be initially to be in deficit for ease of graphical representation - is permanently worsened. If the new trend line lies $2 \%$ below the initial one, relative to public spending tax revenues decline by some $2 \%$ of GDP is it is roughly proportional to income. This will make achieving the surpluses shown in Figure 1 even more challenging.
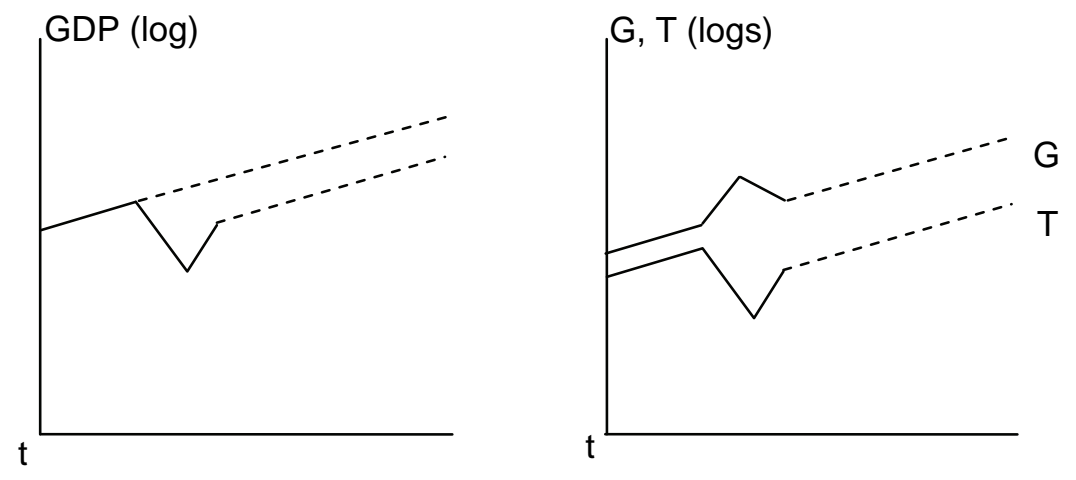

Figure 2. Baseline paths

Yet, this may be unduly pessimistic if we look at past experiences with severe crises. Looking at previous episodes of "bank-centered" financial crises, Reinhart and Rogoff (2008) identify five "big crises”. Since they only look at two years following the crisis, Figure 3 provides a more extended picture of four of Reinhart and Rogoff's Big Five, removing Japan because its economy has not yet really recovered (for reasons that have been much explored). The year indicated in each case is the crisis year as identified by Reinhart and Rogoff. In the two top charts, the GDP recovers its pre-crisis path, computed using the average growth years over the previous 16 years. The situation is less encouraging in the two lower charts. The case of Norway is broadly in line with the baseline assumption in Figure 2. Only in Spain do we see that growth, as opposed to the level, was permanently re- 
duced. However, the mid-1970s correspond to the end of the dictatorship that was followed by deep economic changes.
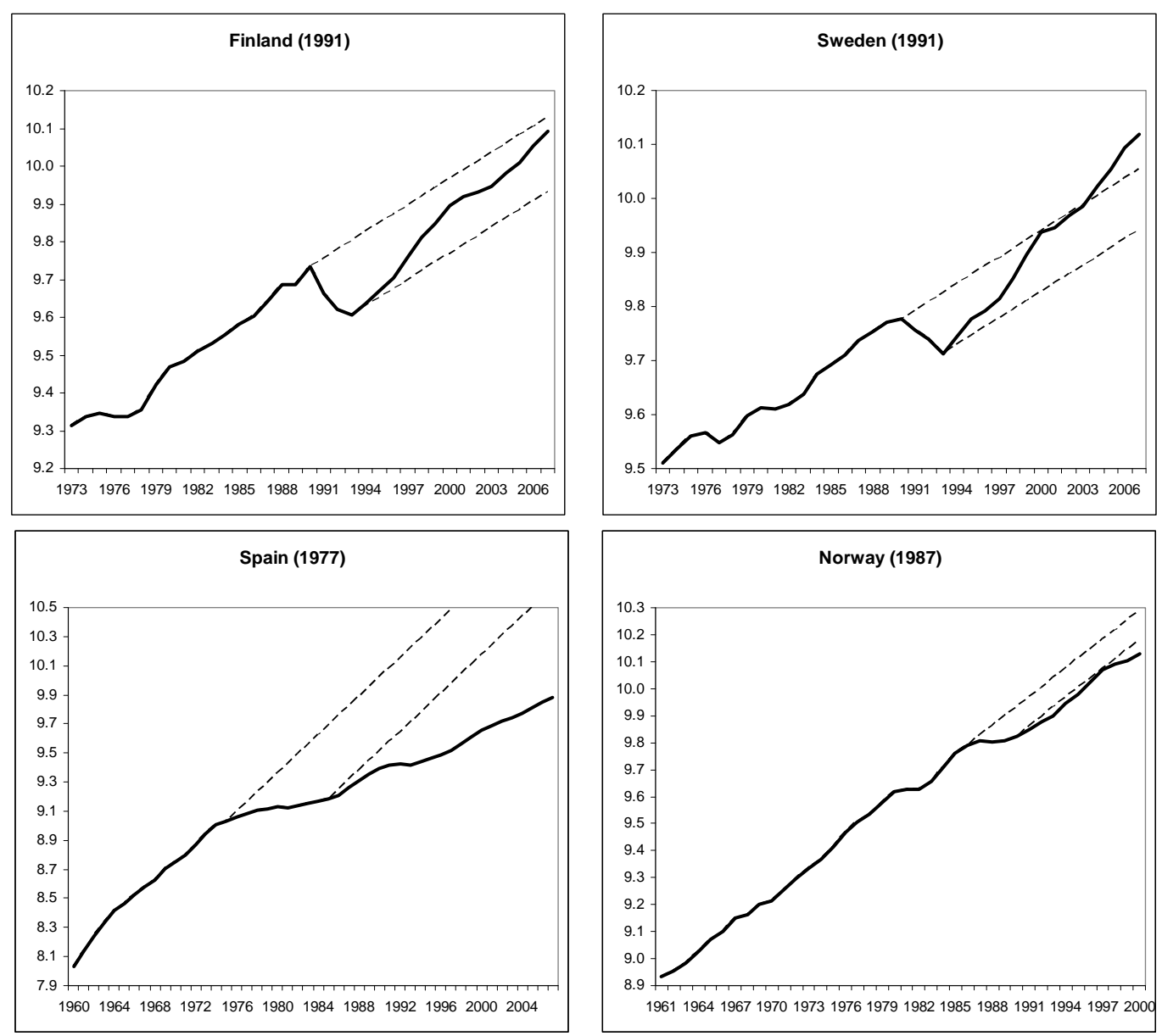

Figure 3. Actual paths of GDP per capita (Logarithm)

Source: Economic Outlook, OECD

The simple calculations underpinning Figure 1 assume that the interest rate exceeds the growth rate by 2 percent. Fast-growing countries face much less demanding conditions. For example, having largely given up on monetary policy with its fixed exchange rate regime, China reacted to the crisis in 2008 with very strong fiscal policy measures, and without any concern for the public debt. 
The conclusion is that, for most countries, there is little doubt that fiscal policies will have to be tightened up relative to the pre-crisis situation. Not only must any deficit be closed, but a further 1 to 2 percent could be needed if the GDP trend is permanently lowered. In addition, a surplus is required to bring the debt down. This can mean a permanent turnaround ranging from 4 to 10 percent of GDP - a challenging effort. The rest of this article examines what it might imply for monetary policy.

\section{The Many Channels of the Struggle for Dominance}

Historically, fiscal authorities that face a daunting task have often found it impossible to resist resorting to inflationary money-financing. This is the fiscal policy dominance assumption. Given that most developed countries have granted them a high degree of independence, central banks are unlikely to be directly and openly pressed to absorb public debts through inflation. The struggle for dominance will have to be more subtle. The new game will shape up as indirect pressure that could lead some central banks to reluctantly adopt policies that they would rather not follow. Three recent examples come to mind. First, Governor Bernanke has publicly admitted that the US Federal Reserve (the Fed) lent to Bear Stearns and AIG, for amounts totaling 5 percent of the Fed's balance sheet, "with great reluctance under extreme conditions" (Bernanke, 2010). Second is the emergency attendance of President Trichet to a mid-February 2010 European Council that pledged their (undefined) support for the embattled Greek government, apparently with his full backing. Presumably he was trying to deflect any suggestion that the ECB might do the job itself. But then, the third example is the May decision of the ECB to buy outright - as opposed to agree to repurchase agreements, as it had so far insisted on doing - public debts that are frowned upon by the markets. Coming a day after EU countries agreed to put up $€ 500$ billion (5\% of the Union's GDP) to guarantee these same debts, the ECB decision looks suspiciously like a case of loss of monetary policy dominance. $^{3}$

These are dramatic and rare events. A natural question is whether armflexing between the two branches of government can operate more discretely

\footnotetext{
${ }^{3}$ This point is further developed in Wyplosz (2010).
} 
through indirect channels, such as the interest and exchange rates and through financial markets.

\subsection{Interest rates}

As policy instruments and channels of transmission, interest rate movements are of primary concern to central banks. Can they be an Achilles' heel in the struggle for dominance? The idea is that government profligacy leads to higher interest rates, which in turn encourages central banks to be more dovish. Both channels need to be examined.

Textbook models tell us that a budget deficit increases the interest rate, but textbooks ignore many details that matter a lot. The short end of the term structure is obviously closely guided by the central bank. Long-term interest rates, on the other hand, respond to much more than monetary policy. They combine inflationary expectations and, indeed, the impact of public borrowing - both the issuing of long-term bonds and expectations of future debt issues. On the other hand, when financial markets are internationally integrated, real interest rates reflect domestic conditions only to the extent that there exist risk premia, and that the exchange rate is expected to change over the relevant horizon.

Given all these influences, it is not surprising that the empirical literature on the real interest rate effects of fiscal policy is ancient, vast and controversial. Much of it has been looking at the US, which is a special, possibly unique case. Indeed all other countries are small relative to the financial markets, and their interest rates tend to be determined relative to the world key currency, the US dollar.

While direct tests fail to turn up evidence, the more recent literature recognizes the possibility that fiscal policy effects on the long-run real interest rate depends on the size of the existing debt, the circumstances (including current budget deficits or surpluses), institutions, and a host of expectations concerning both fiscal policy and financial markets. There is, maybe, the beginning of a consensus.

In a recent study of the US case, Laubach (2009) reports that a one percentage point increase in the deficit/GDP ratio raises the interest rate by 25 basis points, and that a similar increase in the debt/GDP ratio drives the interest rate up by 3 to 4 basis points. Looking at OECD countries, IMF (2009) reports estimates of 20 and 5 basis points, respectively. Both studies 
confirm earlier results that these effects are not linear, rising sharply as the debt increases. The much larger effect of the deficit can be seen as a surprise since theory typically considers that it is the debt that should matter. Then a deficit, which can be temporary and therefore countered by a subsequent surplus, should impact less the interest rate. A plausible interpretation is that, on the contrary, markets tend to see deficits as permanent, or long-lasting enough to recurrently add to the debt. If that interpretation is correct, long real rates should first rise while deficits are large and then decline as fiscal stabilization takes place.

Real Short-Term Interest Rate

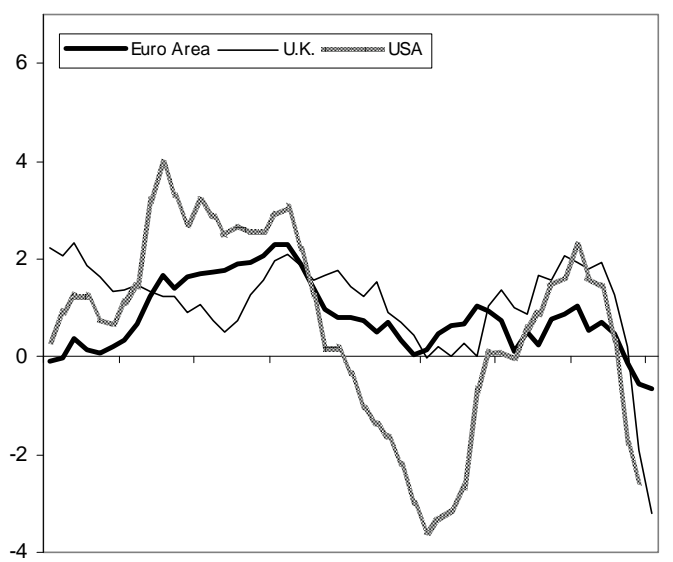

2006M1 2006M7 2007M1 2007M7 2008M1 2008M7 2009M1 2009M7 2010M1
Real Long-Term Interest Rates

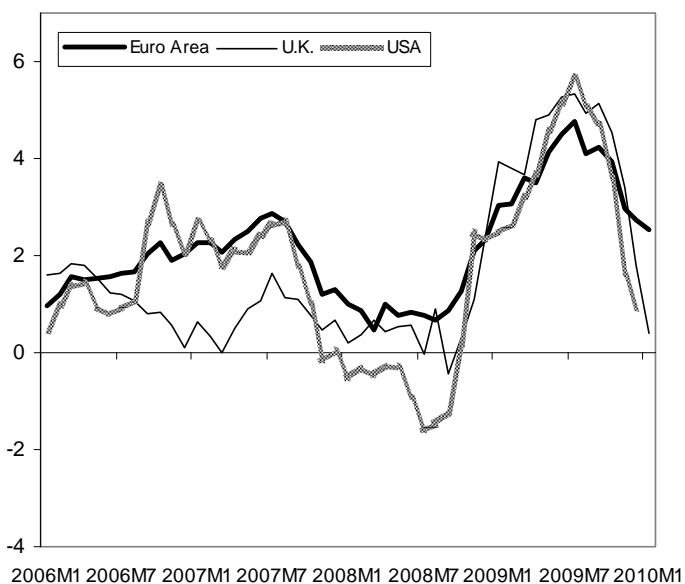

Figure 4. Real interest rates

Sources: International Financial Statistics and central bank websites

Notes: Short-term rates are EONIA (euro area), the Fed Funds (US) and the Interbank rate (U.K.). Long-term rates are 10 year maturity spot rates on government instruments. Current inflation (relative to the same period a year before) is used to compute real rates.

The recent pattern is puzzling at first blush. According to the previous estimates, budget deficits widening by 5 percent to 10 percent of GDP and debts rising by 30 percent should have raised the real interest rates by 2 percentage points, at least. Figure 4 shows that real long-term rates did rise a lot after September 2008, when governments realized that the crisis would be severe enough to warrant exceptional fiscal policy action. This is also when, for the same reason, central banks started to slash the short-term nominal interest rates all the way to the zero lower bound. Yet, the real short-term interest rate rose, as Figure 4 shows, because inflation quickly declined (from ele- 
vated levels) to become negative. It is thus unclear whether the real longterm rates rose because of market concerns with historically high budget deficits and public debts. At any rate, once inflation emerged from negative territory during 2009, both short and long-term real rates declined to low levels.

It seems therefore that real interest rate movements are dominated by swings in inflation rates and, possibly, by monetary policy, including repeated central bank statements that the policy rates will remain very low "for a long period". A way of accounting for both factors is to look at the yield curve. The evidence presented in the leftmost chart of Figure 5 seems to support the presumption that deficits and debts move interest rates up. The rightmost chart, however, shows that nominal long-term rates have declined since the start of the crisis. Together, the two charts imply that the nominal long-term rates have declined by less than the short-term rates. This last observation is troublesome for the view that budget imbalances have played a role because long-term rates always move less than short-term rates. 4 Thus, it is only to be expected that the yield curve steepens when the central bank reduces its policy rate. Much the same - qualitatively and quantitatively - occurred when interest rates were reduced in 2001-2, a period when deficits rose by considerably less.

A plausible conclusion is that the large increases in both public deficits and debts have not yet fully registered in real interest rates. It has been suggested that this is due to a "flight to quality" in the midst of the financial crisis. In this view, government bonds are seen as safer than most privately issued papers. An indication that this is the case is the much-discussed fact that markets have started to discriminate among public debts, not all of them being seen as a safe haven. It follows that long-term rates should rise, possibly considerably, once markets recover risk appetite. The one reason to doubt this interpretation is that risk appetite, as measured by the VIX index, has declined considerably since April 2009, without any increase in government bond rates or in the risk premia on suspicious public debts.

\footnotetext{
${ }^{4}$ The common interpretation is the expectations hypothesis, which implies that long-term rates are averages of current and future short-term rates, along with the view that short-term rates tend to regress to their means.
} 

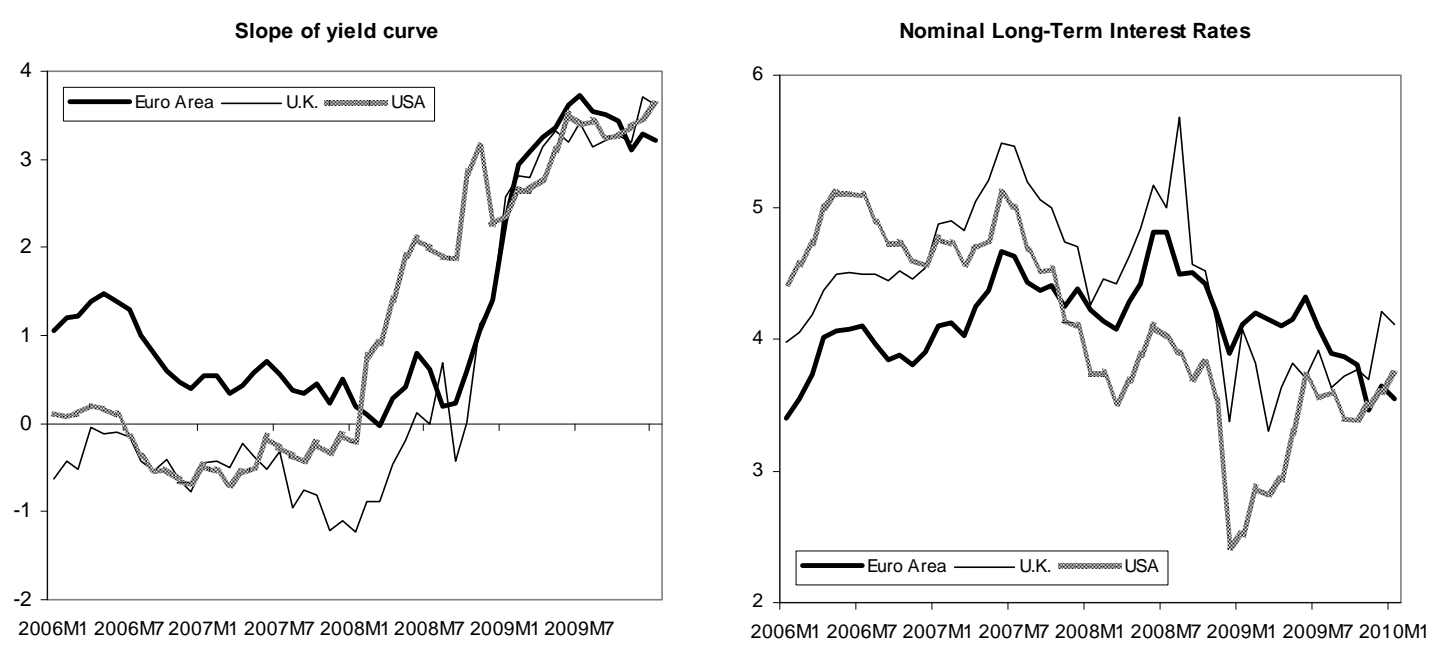

Figure 5. Slope of the yield curve and nominal rates

Sources: IFS and central bank websites.

Note: The slope is the difference between 10 year bond rates and the short-term rate, see Figure 4 for details.

While the impact of fiscal policy on interest rate is at best limited, there remains the question of the influence of interest rates on central banks. As previously noted, central banks can control the short-term rates, which have limited effects on the economy, the exception being countries like the UK where bank lending conditions are indexed on these rates. The more important interest rates are medium to long rates that represent the bulk of borrowing, and thus affect spending by households and firms. Imagine that large deficits lead to an increase in the long-term interest rate. This has a contractionary effect, indeed it is the presumed channel for the textbook crowdingout effect. Would that lead central banks to become more accommodative than otherwise?

Central banks insist that they do not react mechanically to events. This implies that a central bank will not react automatically to a long-term interest rate increase. Its decision will presumably involve the whole of range of its usual concerns. Even in the mechanical description of the Taylor rule, central banks only respond to expected inflation and expected output. In this view, the central bank will respond to the interest rate change in a way that upholds its inflation and output objectives. As long as the central bank is 
independent, it is quite unlikely that monetary policy dominance can be challenged via the interest rate.

\subsection{The exchange rate}

The exchange rate is another important concern for central banks. Inasmuch as fiscal policy affects exchange rates, this variable can be seen as another battleground in the struggle for dominance when it is freely floating. ${ }^{5}$ When it is fixed and adjustable, fiscal dominance is established, as discussed below.

The link between fiscal policy and the exchange rate is all but clear. Textbook models in the IS-LM tradition predict that, when the exchange rate is freely floating, a fiscal expansion is met by an exchange rate appreciation as the expansion raises the demand for money and prompts capital inflows. This appreciation undermines the effectiveness of fiscal policy. As a result, the central bank is on the spot since it alone can prevent the appreciation and thus support fiscal policy. ${ }^{6}$

The empirical literature is very limited and yet contradictory. The most recent contribution by Bénétrix and Lane (2009), who estimate the impact of fiscal policy shocks on the real exchange rates for a panel of 11 euro area countries and for a panel of four non-euro area countries, finds opposite effects between individual euro area countries that have de facto fixed exchange rates amongst themselves (raising public spending leads to a real appreciation) and flexible exchange rate countries (the real exchange rate depreciates). A plausible conjecture is that, as with the interest rate, expectations play a crucial role.

Of independent interest is what happened since the beginning of the crisis, which cannot yet be subjected to formal testing. Figure 6 simply relates the change in the real exchange rate from June 2007 to October 2009 (last available observation) to the change in public debts from 2007 to 2009. For all OECD countries, treating the euro area as a single observation, the left-

\footnotetext{
${ }^{5}$ This is the one potential limit to the ECB's otherwise total independence. The Treaty (Art.219) opens the door for governments to "formulate general orientations" on exchange rate policy. The ECB, naturally, insists that this only concerns formal exchange rate arrangements while some governments have made comments on the level of the exchange rate.

${ }^{6}$ Neo-classical models predict the opposite because private wealth is reduced by future tax liabilities and prices decline. Price rigidity, as in New Keynesian models, undermines this effect, but these models have little to say about money and capital flows.
} 
most chart shows that the association is negative, but that the partial correlation coefficient is not significant. Focusing on euro area member countries in the right-hand chart, the partial correlation is significantly negative. While this runs against the results reported by Bénétrix and Lane (2009), it must be emphasized that partial correlations do not deal with causality. In addition, the situation remains very fluid and the pattern may change before we can conduct forensic studies of the crisis. For example, the euro has depreciated by some 10 percent since the last observation, reportedly because of market concerns with some euro area member countries public debts.

All countries (Euro Area as one unit)

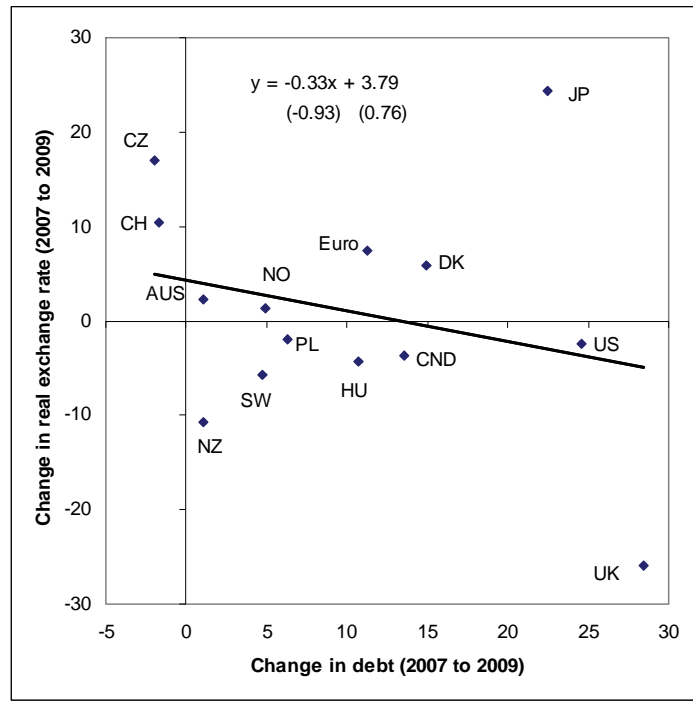

Euro Area Member Countries

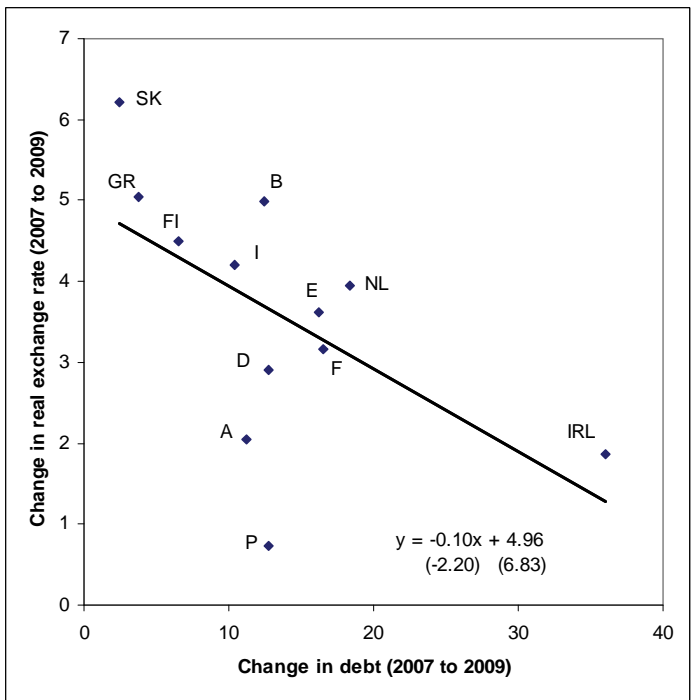

Figure 6. The real exchange rate and public debts in the crisis in OECD countries Changes from 2007 to 2009

Sources: International Financial Statistics, IMF and Economic Outlook, OECD

Notes: The real effective exchange rate is deflated by $\mathrm{CPI}$, change is in percent. Debt to GDP ratio, change in percent of GDP. An increase is a real appreciation.

The period since 2007 is relatively short, especially regarding price movements. Were real exchange rate movements driven by nominal changes, as is usually the case, see e.g., Rogoff (1996)? Looking at nominal effective exchange rates, instead, reveals no correlation with debt ratios for the sample countries of the left-hand chart in Figure 6. Looking at the euro area member countries, the relationship is strongly positive, but it disappears when two outliers, Austria and Ireland, are excluded. Since all these countries share the 
same currency, differences in effective rates reflect the composition of trade: Ireland's effective rate appreciated because Britain is an important trade partner and the Sterling depreciated by some 25 percent; while Austria's effective rate remained virtually unchanged, reflecting the importance of its trade links with Germany.

All in all, there is little evidence of any systematic effect. Assuming that there is one, what impact would it have on a central bank? Pretty much as with the interest rate, the central bank is likely to focus on the impact of the exchange rate on the expected evolution of inflation and the output gap, i.e. it will react to fiscal policy but with the intention of achieving its usual objective(s). The situation is radically different when the exchange rate is pegged since, in this case, monetary policy is not an autonomous instrument and the central bank is not truly independent. Not surprisingly, fiscal policy then is likely to "force" the central bank to change its stance as it intervenes in the foreign exchange market to uphold the declared parity. Still, the parity cannot be maintained if fiscal policy keeps imparting a bias in either direction. With parity adjustments, however, fiscal dominance is established.

The distinction between fixed and flexible exchange rates is not as clear cut as it seems. Because the exchange rate directly affects its objectives inflation and output - a central bank is unlikely to ignore its evolution. Inasmuch as appreciation reduces inflation and threatens to bring to negative territory, or hurts growth, or both, a central bank may find it necessary to adopt a more expansionary stance. Put differently, in a small open economy where the exchange rate is an important variable, the dominance issue is wide open. This observation applies to the Nordic countries.

\subsection{Markets as referees}

The previous section looked at "normal” effects of fiscal policies. However, financial markets occasionally react violently, which leads to crisis situations. Furthermore, crises are often contagious, as shown in Eichengreen et al. (1996) and Kaminsky and Reinhart (2000). Once markets have detected a vulnerability in the case of one country, they soon look around for similar situations. In this event, the crisis spreads to countries that would probably not have been noticed without the initial crisis, an instance of self-fulfilling crises. Examples of this phenomenon have accumulated in recent years. This happened to Finland and Sweden in the early 1990s. The Tequila Crisis also 
spread through South America in 1995 following a successful attack on the Mexican peso. In 1997-98, one South-East Asian country after another faced heavy hardship following the Thai Crisis. Soon thereafter, a crisis in Russia spread to other former Soviet Union countries and, apparently, to Norway and Brazil as well. The 2001 crisis in Argentina again shook South America. Now we see the Greek crisis threatening to move to other euro area countries.

In all of these cases, fiscal indiscipline is a center stage. We know that self-fulfilling crises occur in the presence of some vulnerability, quite often the fiscal situation. Markets start worrying about a default and, by running on a country's currency, they effectively provoke the default. The generally massive depreciation that ensues soon leads to large price increases. Even though the nominal exchange rate often partly recovers once the panic has come to an end, price increases are permanent - in fact the real exchange rate is usually restored to its pre-crisis level. Unless it wants to force a revaluation and a price decline, the central bank is compelled to ratify the situation, in effect increasing the money supply. Seigniorage and debt depreciation represent a case of fiscal policy dominance, and markets running on currencies make this possible.

\section{Monetary policy after the crisis}

The new world in which central banks will operate differs from the pre-crisis world in many ways. The inflation-targeting framework has been shaken, but probably not fatally wounded. The old myth that central banks could exercise discretion in lending-in-last-resort operations has been removed. Large public debts may raise the long-term interest rates for a decade or two, steepening ceteris paribus the yield curve. Finally, fiscal policy could be impaired in many countries. This section takes up these issues.

\subsection{Is inflation targeting passé?}

While inflation targeting has become the standard during the 2000s, a number of objections have been raised. The ECB never acknowledged that it was a de facto inflation targeter, because it famously stood by the Bundesbank two-pillar legacy, which pays some respect to monetary aggregates (Issing, 
2001; Beck and Wieland, 2007). Given its legal brief, the Fed so far also feels that it cannot admit to practicing inflation targeting. The Bank of Japan has also steadfastly refused to admit any strategy. A small number of papers had also argued that central banks should not ignore asset price developments, see e.g., Cecchetti et al. (2000).

Once the crisis erupted, these criticisms have quickly resurfaced. Leijonhufvud (2009) offers a scathing attack on inflation targeting, which he views as simplistic. This point, however, ignores much of the more recent literature on complexity and robust rules, for example Orphanides and Williams (2007). More central is the question of whether monetary aggregates were providing important information that too many central banks had been convinced to ignore or downplay. As far as I know, this has not yet transpired into scholarly work, but some researchers have started to argue that the crisis has vindicated the ECB strategy.

The debate between and the ECB and its critics is muddled by extraneous side considerations. One of them is the question of whether money matters for the transmission of monetary policy. The view that it does not has been convincingly advanced by Woodford (2008), but the crisis has exposed its limits. In particular, the assumption that markets are complete removes financial considerations from the models used to examine the channel of monetary policy. The lesson from the crisis, that credit growth is a useful indicator, is unmistakable and has been taken on board in new research, see Curdia and Woodford (2009). The other debate is whether looking at monetary aggregates is incompatible with inflation targeting.

This second debate is merely definitional. For many years, Svensson (1999) and others have argued that the inflation targeting strategy is meant to be flexible. This means that credit growth can be looked at, even responded to, if needed. The same argument is now used by Svensson (2010) to argue that asset price movements can readily be incorporated in the strategy. Before the crisis, many inflation-targeting central banks - for instance the Bank of England - strenuously and explicitly refused to admit that they should be influenced by asset price inflation. ${ }^{7}$

The question is whether the flexible definition of the strategy does not become vacuous when it is made to accommodate more concerns. By stating

\footnotetext{
${ }^{7}$ Central banks that did not officially adopt the inflation targeting strategy, such as the Fed and the ECB, also rejected any direct role for asset prices over and beyond their impact on inflation and output.
} 
that it looks at everything that matters for future inflation and economic growth, a central bank does not commit to inflation targeting. The strategy requires a lot more: identifying a target inflation rate and an acceptable range around it, publishing forecasts of inflation and the output gap at the policy horizon - and acknowledging the horizon - and a clear statement of how the central bank views the trade-off between inflation and output over the relevant period. Credit growth and asset prices influence all of the above so, in a way, their influences must be part of the strategy if the forecasting exercise is conducted correctly. What is at stake is whether the central bank is ready to acknowledge that credit may be growing too fast or that asset prices are embarked on a bubble-like path, and to explain what policy conclusion it draws. In the period leading up to the crisis, both phenomena were under way in many countries and yet most central banks chose not to discuss the situation. Most, in fact, consciously decided not to modify their policies.

The next issue is what to do about unduly rapid credit growth or asset price inflation. Early critics of the inflation-targeting strategy suggested that the interest rate should be raised above what the relevant forecasts would suggest because of the risk of crisis (Cecchetti et al., 2000). The counterargument was that sharply raising the interest rate was sure to precipitate a slowdown, possibly even a recession, while diagnosing excessive credit growth or an asset price bubble was a highly uncertain undertaking. The emerging post-crisis consensus, as stated in Svensson (2010), is that it is incumbent upon central banks to detect such potential sources of crisis, but that the policy response is not to raise the interest rate. Excessive credit growth or asset price bubbles are the consequences of market failures, possibly exacerbated by inappropriate regulation. The second best principle is to use the instrument that most directly addresses the failure. In general, the interest rate is unlikely to be a second best instrument. For example, the fast increase in subprime loans, arguably the cause of the crisis, involved market failures (the originate and distribute model, which separates risk-taking and risk-bearing, and a severe information asymmetry uncorrected by adequate consumer protection), misguided market interventions (Fannie Mae and Freddy Mac), and inadequate worldwide bank supervision (Basel 2 did not catch the shadow banking system). Righting some of these wrongs in good time could probably have averted the crisis while raising the interest rate, even very strongly, would probably have brought the crisis forward. 
The implication is that the inflation targeting strategy has broadly survived the test, but that some adjustment is needed. Central banks no longer can pretend that asset prices and developments on the credit market are merely indicators to be factored in when making inflation and output forecasts. They must acknowledge that they share responsibility for financial stability with regulators and supervisors. They should continue to use the interest rate to target inflation taking account output developments as in the now-traditional flexible version of the strategy, but they must recognize that there are times when threats to financial stability warrant an explicit inflection. This can be rationalized as a fat-tail phenomenon where expected inflation and output gap no longer appropriately describe the situation. At the same time, central banks should not take full responsibility for financial stability because the most adequate instruments belong to government agencies.

\subsection{The Zero Lower Bound}

The Japanese experience and a temporary deflation scare in 2003 among OECD countries have brought back the old fear of a liquidity trap (Krugman, 2003). It has finally happened among many of the advanced economies when interest rates were brought to the zero lower bound. One issue is whether monetary policy loses its effectiveness when the interest rate cannot be lowered any further. Another issue is what can be done when the bound is reached. A third issue is how to avoid the zero lower bound.

The effectiveness issue boils down to preventing a liquidity trap. With interest rate stuck at zero, the central bank is left with two instruments: the quantity of money and the management of expectations. It is very unlikely that expectations can be managed without action, as some central bankers sometimes seem to believe. The question, then, is whether pushing more money into the economy has an effect at all or whether it is simply shelving it in trap.

The Bank of Japan's experiment with quantitative easing has drawn mixed, mostly negative appraisal, see Ito (2009). Part of the reason is that Japanese banks were allowed to not fully recognize their losses and to remain undercapitalized. As a result they hoarded liquidity instead of lending. The Bank of Japan then moved to flatten the yield curve by buying longdated securities, and apparently achieved to do so. Yet, for all these efforts, a 
decade later inflation remains nil or negative. This shows that massive quantitative easing can be ineffective in the presence of a liquidity trap.

Two proposals have been advanced for trying to exit from a liquidity trap. Svensson (2003) advocates unsterilized foreign exchange market interventions. The hoped-for exchange rate depreciation should generate both inflation and increased demand for domestic goods. This makes good sense when just one country is caught in a liquidity trap, like Japan in the 1990s; but it cannot be used when a large number of countries are simultaneously trapped. More generally, it raises a serious beggar-thy-neighbor issue that requires some international agreement (informal to start with). Buiter and Panigirtzoglou (2003) advocate imposing a negative interest on money, including cash. This would lower the real interest rate but it remains unclear whether it would also break the negative sentiment that deters spending by firms and households in a recession situation. In addition, the costs of organizing such a scheme are bound to be large. Except for a couple of foreign exchange interventions in 2009-10 by Australia and Switzerland, none of these two solutions have been implemented.

It is far too early to pass judgment on the effectiveness of quantitative easing efforts conducted by several central banks in 2009. Section 3.1 makes the point that long-term interest rates did not rise as large budget deficits opened up. One possible reason is that quantitative easing, in particular the willingness of central banks to hold long-dated assets, has been effective. On the other hand, bank credit has not expanded much, but careful research is needed to determine whether it is demand or supply that has acted as a force of restraint.

The crisis has brought home the view that liquidity traps should not be confined to textbook footnotes or to the economic history of the 1930s. It seems - again, this point will have to be formally investigated - to confirm the lesson from Japan, namely that liquidity traps are potentially dangerous because we do not have fool-proof instruments to exit once we are caught in one of them. Obviously, we now need to think how monetary policy should be adjusted to reduce the incidence of liquidity traps.

The main suggestion thus far is that central banks should normally keep the nominal interest rate far enough from the zero lower bound. Since the real rate cannot permanently differ from its natural level, the only way to widen in normal times the distance of the nominal rate from zero is to raise the inflation target. This reasoning, which can be found in Begg et al. (1998) 
and Gerlach et al. (2009), has recently attracted attention with Blanchard et al. (2010), who consider 4 percent as a reasonable inflation target.

The idea of aiming at a higher inflation rate during normal times to reduce the odds of a deflation obviously runs again the current orthodoxy. Yet, in many advanced countries, inflation has moved close to, or indeed into, negative territory twice during the recent low inflation period. The question is whether the trade-off, accepting higher average inflation to limit the risks of deflation, is meaningful. A back of the envelope calculation can be done as follows. The Taylor rule provides the interest rate $i$ that the central bank sets, given foreseen inflation $\pi$ and output gap $x$, given the natural real rate $r$ and the inflation target $\pi$ :

$i=r+\bar{\pi}+a(\pi-\bar{\pi})+\beta x$

As is well known, the rule provides a decent description of what most central banks do. We can simulate the interest rate that the central bank would have set if it had followed the Taylor rule. Assuming for simplicity that the resulting interest rate is normally distributed, by observing its mean and standard deviation, we can infer the probability of hitting the zero lower bound. Further assuming that the implicit inflation target has been constant over the sample period, we can change $\pi$ and compute the new mean and the associated probability. An even simpler procedure is to simply observe the actual interest rate, assume that it is normally distributed, and infer the probability that it be negative.

The results of this calculation are reported in Table 1, and are based on the US experience from 1970 to 2009. The boldfaced row corresponds to actual annual observations. Columns (2) and (3) show the mean and standard deviation of the policy interest rate i. Column (4) reports the probability that $\mathrm{i}<0$, which stands at 3.4percent or once every 30 years. Over the last 40 years, the Fed reached the lower bound once and came close to it another time. Columns (6) to (8) provide the same information where the interest rate is now simulated using the Taylor rule with the conventional values $\alpha=1.5$ and $\beta=0.5$ and with $r$ such that the average of the simulated nominal interest rate average is the same as the sample average of the actual rate. The Taylor rule leads to a more activist policy, and therefore to a higher probability of bringing the interest rate to zero. Many papers show that an inertial 
version of the rule tracks the actual interest rate more closely. In the present case, this would deliver results closer to those shown in Column (4), thus offering less of an alternative to these results.

Table 1. Probability of hitting the zero lower bound

\begin{tabular}{|c|c|c|c|c|c|c|c|c|}
\hline \multirow[b]{2}{*}{$\begin{array}{l}\text { Average } \\
\text { inflation }\end{array}$} & \multicolumn{4}{|c|}{ Actual interest rate } & \multicolumn{4}{|c|}{ Taylor rule interest rate } \\
\hline & Mean & $\begin{array}{l}\text { Standard } \\
\text { deviation }\end{array}$ & $\begin{array}{r}\text { Probability } \\
\text { (constant } \\
\text { SD) }\end{array}$ & $\begin{array}{r}\text { Probability } \\
\text { (variable } \\
\text { SD) }\end{array}$ & Mean & $\begin{array}{l}\text { Standard } \\
\text { deviation }\end{array}$ & $\begin{array}{r}\text { Probability } \\
\text { (constant } \\
\text { SD) }\end{array}$ & $\begin{array}{r}\text { Probability } \\
\text { (variable } \\
\text { SD) }\end{array}$ \\
\hline (1) & (2) & (3) & (4) & (5) & (6) & (7) & (8) & (9) \\
\hline 0 & 1.7 & 2.8 & $30.7 \%$ & $27.0 \%$ & 1.7 & 3.8 & $35.3 \%$ & $32.3 \%$ \\
\hline 1 & 2.7 & 2.9 & $21.3 \%$ & $17.6 \%$ & 2.7 & 3.9 & $27.6 \%$ & $24.3 \%$ \\
\hline 2 & 3.7 & 3.1 & $14.1 \%$ & $11.3 \%$ & 3.7 & 4.1 & $20.8 \%$ & $18.0 \%$ \\
\hline 3 & 4.7 & 3.2 & $8.4 \%$ & $6.8 \%$ & 4.7 & 4.3 & $15.1 \%$ & $13.3 \%$ \\
\hline 4 & 5.7 & 3.3 & $4.8 \%$ & $4.2 \%$ & 5.7 & 4.4 & $10.6 \%$ & $9.7 \%$ \\
\hline 4.6 & 6.3 & 3.4 & $3.4 \%$ & $3.4 \%$ & 6.3 & 4.6 & $8.6 \%$ & $8.6 \%$ \\
\hline 5 & 6.7 & 3.6 & $2.5 \%$ & $3.0 \%$ & 6.7 & 4.8 & $7.1 \%$ & $7.9 \%$ \\
\hline 6 & 7.7 & 3.7 & $1.2 \%$ & $1.9 \%$ & 7.7 & 5.0 & $4.6 \%$ & $6.0 \%$ \\
\hline
\end{tabular}

Source: Fed Funds rate and US CPI inflation are from International Financial Statistics; the US output gap is from the OECD Economic Outlook. Sample period: 1970-2009.

Note: "Constant SD" takes the actual standard deviation (boldfaced in column (3) or (7) to compute the probability; "Variable SD" adjusts the standard deviation to a different mean as shown in column (3) or (7), where a raising the mean by unity is accompanied by a $4 \%$ increase in standard deviation, see Rother (2004).

The other rows examine what would have been the case if inflation had been lower and, using Fisher's principle, the nominal interest rate would have been lowered accordingly. For example, the third row corresponds to an average inflation rate of 2 percent, which is assumed to be the central bank target, successfully achieved on average. Since this inflation is 2.6 percentage points below the actual sample average, the average interest rate is assumed to be lower by the same amount. Column (4) indicates that the probability to hit the zero lower bound increases considerably to 14.1 percent, i.e. one year out of seven. Similar results are obtained with the Taylor rule simulation in Column (8), where it is assumed that the target inflation rate is the same as the average rate.

It should be emphasized that this crude back-of-envelope calculation is presented for illustrative purpose. Many assumptions are clearly dubious. It is known, for example, that the interest rate distribution is skewed. In addition, the (implicit) target inflation rate must have varied quite a bit over the sample period. It is also known that inflation and interest volatility rises with the inflation level. Columns (3) and (7) account for the latter effect, using the volatility elasticity as computed by Rother (2004). The implied prob- 
abilities are shown in Columns (5) and (9). As expected, the volatility effect reduces the probability of hitting the lower bound as the inflation rate declines and, conversely raises it as inflation increases. The effect is found to be too small to offset the role of the distance from the inflation target from zero.

With all the caveats required when interpreting these results, the exercise suggests that the tradeoff exists. Raising very moderately the target (and average) inflation rate probably significantly improves the odds of escaping the zero lower bound.

\subsection{Implications of too-big-to-fail}

Just one event, the collapse of Lehman Brothers, has changed part of the Bagehot doctrine: central banks cannot decide whether to intervene or not when a systemically important bank is collapsing. The implication is that financial institutions too big to fail have a de facto guarantee of bailout in case they fail. The further implication is that every financial institution has a strong incentive to become too big, or too interconnected to fail.

The crisis has also amply illustrated the old mantra that central banks do not have the time, or even the ability to determine whether a financial institution is suffering from illiquidity or from insolvency. In fact, as shown by Kiyotaki and Moore (1997), the distinction may well be meaningless when illiquidity leads to fire sales and to sharply declining asset prices.

The threat of a financial meltdown represents another ground for the battle over dominance. Because one of their duties is to ensure a smooth functioning of financial markets, central banks are committed to "do something" when banks and key financial institutions are in a precarious situation. At the very least, they must provide liquidity. At worst, they must rescue banks. In principle, a bank bailout is a fiscal responsibility, but governments can sit out for a while, which central banks cannot, because they are engaged in the markets in continuous time. The resulting blurring of the distinction between fiscal and monetary duties is a threat to monetary policy dominance.

Because banking crises are so dangerous, central banks may be tempted to err on the side of easier policy when in doubt or when the situation becomes dangerous. This temptation is very different from the earlier argument in favor of a higher inflation target. In the former case, the central bank continues to enforce its rule whereas in the latter case it deviates from its chosen 
strategy in the hope of avoiding forced lending in last resort. This can be seen as another dominance struggle, this time between central and commercial banks.

Both forms of dominance struggle explain that central banks have a huge stake in improving financial regulation, and in having it rigorously enforced. Whether the proper model is to entrust the regulation and supervision of individual institutions to the central bank is a complex issue that does not belong to a paper on monetary policy, except to note that it would not necessarily strengthen central bank dominance over both the government and large financial institutions.

The proper response to the now-exposed obligation to lend in last resort is to deal directly with the moral hazard that it creates. Macroprudential regulation and supervision is now seen as probably the second best policy response, see Brunnermeier et al. (2009). Likely to be implemented in the near future, macroprudential supervision squarely belongs to central banks. Analytically, it involves aggregating individual bank-level information, a fairly complex procedure, and linking this information to macroeconomic and financial developments. The skills for this work are in central banks. Of course, other agencies could acquire these skills, but they would anyway need to agree with central banks about the macroeconomic developments.

\subsection{Steeper yield curves}

It was argued in Section 2.1. that high debts are likely to eventually lift longterm real interest rates, corresponding to the amount of long-term public debt that will have to be held by the private sector. If this assumption is correct, it means that in the coming years the yield curve will be ceteris paribus steeper than before the crisis. This effect must be compared to other possible changes likely to also affect the long end of the yield curve. Partly in response to higher real interest rates, saving behavior by household and in emerging market countries could increase, thus partially offsetting the debt effect. The overall impact of the crisis may therefore be limited.

Still, assuming that the yield curves become steeper, will that affect monetary policy? For a given short-term policy interest rate, policy will be more restrictive than when the curve was steeper. This can be corrected most easily and should not create any difficulty for central banks except that it could raise the probability of reaching the zero lower bound. Another policy 
response is for central banks to continue the practice, started during the crisis, of acquiring long-dated securities.

\subsection{Impaired fiscal policies}

Large public debts are likely to impair fiscal policies. Rolling back debts will force governments to aim at structural surpluses, imparting a contractionary bias until this is achieved. In addition governments are likely to be reluctant to reopen deficits once they have closed them. If this conjecture is correct, monetary policy will be seen as the main, if not only, macroeconomic policy instrument.

This is not a large change, since conventional wisdom before the crisis already held that monetary policy is the countercyclical instrument of choice: for a number of reasons. Decisions can be taken fast and are less subject to political motives than fiscal policy. The interest rate instrument is simpler to use than changing taxes or public spending. The effects are better known, both theoretically and empirically.

Pushing ever more responsibility onto central banks does not necessarily affect dominance. What is important, though, is that monetary policy remains effective under most plausible conditions. This issue is treated in Section 2.2.

\section{Conclusion}

The crisis is leaving most but not all advanced countries with historically high debt levels. As governments need to focus on fiscal discipline, they may rely on central banks to deliver countercyclical policies and possibly even weigh on them to provide relief through inflationary finance. The monetary policy dominance regime in place is therefore under threat. Yet, the biggest threat to monetary policy dominance may well come from the current financial system, that it has become clear that central banks have no choice but to bail out systemically important financial institutions. How can central banks react?

With strong central bank independence, the debt is unlikely to be monetized. Whether long-term real interest rates will be permanently higher or not depends on a host of factors, not just about public debts. Anyway, central 
banks have learned how to intervene along the yield curve. It may well be that fiscal policy will not play much of a countercyclical role, but it has rarely done so in recent years, so little is changed.

The real challenges for central banks lie elsewhere. First, the 2000s have revealed the danger of disinflation when inflation targets are set very low. ${ }^{8}$ The dominating current sentiment, that inflation should not be allowed to reappear, makes it difficult to consider higher inflation targets. But the issue must be debated in earnest.

The second challenge is to design regulations that reduce the too-big-tofail syndrome and to carry out strict supervision. Central banks must be involved, and possibly in charge of macro-prudential supervision. Serious consideration could even be given to attribute micro- prudential supervision of central banks. There are solid arguments to avoid dragging central banks into this domain but the generalized failure of supervision agencies before the crisis - and, in some countries, after the crisis - means that there should not be any sacred cow.

\section{References}

Akerlof, G.A., Dickens, W.T. and Perry, G.L. (1996), The macroeconomics of low inflation, Brookings Papers on Economic Activity 1, 1-59.

Beck, G.W. and Wieland, V (2007), Money in monetary policy design: A formal characterization of ECB-style cross-checking, Journal of the European Economic Association 5, 524-533.

Begg, D., De Grauwe, P., Giavazzi, F., Uhlig, H. and Wyplosz, C. (1998), The ECB: Safe at any speed?, Monitoring the European Central Bank 1, CEPR.

Bénétrix, A. and Lane, P. (2009), Fiscal shocks and the real exchange rate, IIIS Discussion Paper 286, Trinity College Dublin.

Bernanke, B.S. (2010), Federal Reserve's exit strategy, Testimony before the committee on financial services, U.S. House of Representatives, Washington, D.C.

Blanchard, O.J., Dell'Ariccia, G. and Mauro, P (2010), Rethinking macroeconomic policy, IMF Staff Position Note.

Brunnermeier, M., Crocket, A., Goodhart, C., Persaud, A. and Shin, H. (2009), The fundamental principles of financial regulation, Geneva Reports on the World Economy 11, ICMB and CEPR.

\footnotetext{
${ }^{8}$ An earlier literature (Akerlof et al. 1996; Wyplosz 2001) has also argued that relative price adjustments are difficult at very low inflation rates.
} 
Buiter, W.H. and Panigirtzoglou, N. (2003), Overcoming the zero bound on nominal interest rates with negative interest on currency: Gesell's solution, Economic Journal 113, 723-746.

Canzoneri, M., Cumby, R. and Diba, B. (2001), Is the price level determined by the needs of fiscal solvency?, American Economic Review 91, 1221-38.

Cecchetti, S., Genberg,H., Lipsky, J. and Wadhwani, S. (2000), Asset prices and central bank policy, Geneva Reports on the Word Economy 2, ICMB and CEPR.

Curdia, V. and Woodford, M. (2009), Credit frictions and optimal monetary policy (http://www.columbia.edu/ mw2230/credit_0709.pdf).

Cukierman, A., Webb, S. and Neyapti, B. (1992), Measuring the independence of central banks and its effect on policy outcomes, World Bank Economic Review 6, 353-398.

Eichengreen, B. (1994), International Monetary Arrangements for the $21^{\text {st }}$ Century, The Brookings Institution, Washington, D.C.

Eichengreen, B., Rose, A. and Wyplosz, C. (1996), Contagious currency crises, Scandinavian Journal of Economics 98, 463-84.

Fischer, S. (2001), Exchange rate regimes: Is the bipolar view correct?, Journal of Economic Perspectives 15, 3-24.

Gerlach, S., Giovannini, A., Tille, C. and Viñals, J. (2009), Are the golden years of central banking over? The crisis and the challenges, Geneva Reports on the World Economy 10, ICMB and CEPR.

Ghosh, A., Gulde, A.M. and Wolf, H.J. (2000), Currency boards: More than a quick fix?, Economic Policy 31, 269-336.

Grilli, V., Masciandaro, D. and Tabellini, G. (1991), Political and monetary institutions and public financial policies in the industrial countries, Economic Policy 13, 341-92.

IMF (2009), The state of public finances cross-country fiscal monitor, IMF Staff Position Note, November.

Issing, O. (2001), Monetary theory as a basis for monetary policy: reflections of a central banker, in A. Leijonhufvud (ed.), Monetary Theory and Policy Experience, Palgrave, New York.

Ito, T. (2009), Zero interest rate policies and quantitative easing, in M. Dewatripont, X. Freixas and R. Portes (eds.), Macroeconomic Stability and Financial Regulation: Key Issues for the G20, CEPR, London.

Kaminsky, G.L. and Reinhart, G.M. (2000), On crises, contagion, and confusion, Journal of International Economics 51, 145-168.

Kiyotaki, N. and Moore, J. (1997), Credit cycles, Journal of Political Economy 105, 211-48.

Krugman, P. (1998), It’s baaack! Japan’s slump and the return of the liquidity trap, Brookings Papers on Economic Activity 2, 137-187.

Laubach, T. (2009), New evidence on the interest rate effects of budget deficits and debt, Journal of the European Economic Association 7, 858-885.

Leijonhufvud, A. (2009), Macroeconomics and the crisis: A personal appraisal, Policy Insight 41, CEPR.

Orphanides, A. and Williams, J.C. (2007), Inflation targeting under imperfect knowledge, in F. Mishkin and K. Schmidt-Hebbel (eds.) Monetary Policy under Inflation Targeting, Central Bank of Chile, Santiago. 
Reinhart, C.M. and Rogoff, K.S. (2008), Is the 2007 U.S. sub-prime financial crisis so different?, An international historical comparison, NBER Working Paper 13761.

Rogoff, K. (1996), The purchasing power parity puzzle, Journal of Economic Literature 34, 647-668.

Rother, P. (2004), Fiscal policy and inflation volatility, ECB Working Paper 317.

Sargent, T. and Wallace, N. (1981), Some unpleasant monetary arithmetic, Federal Reserve Bank of Minneapolis Quarterly Review 5, 1-17.

Svensson, L.E.O. (1999), How Should monetary policy be conducted in an era of price stability?, in New Challenges for Monetary Policy, Federal Reserve Bank of Kansas City, Kansas.

Svensson, L.E.O. (2003), Escaping from a liquidity trap and deflation: The foolproof way and others, Journal of Economic Perspectives 17, 145-166.

Svensson, L.E.O. (2010), Inflation targeting after the financial crisis (http://people.su.se/ leosven/papers/100212e.pdf).

Woodford, M. (2008), How important is money in the conduct of monetary policy?, Journal of Money, Credit and Banking 40, 1561-1598.

Wyplosz, C. (2001), Do we know how low should inflation be?, in A. Garcia Herrero, V. Gaspar, L. Hoodguin, J. Morgan and B. Winkler (eds.), Why Price Stability?, European Central Bank, Brussels.

Wyplosz, C. (2010), Picking up the broken pieces when the European debt crisis is over, unpublished manuscript, Graduate Institute, Geneva. 


\section{Appendix: Formula used in Figure 1}

Using the notations from Footnote 2, the budget constraint is:

$b_{t+1}-b_{t}=(r-g) b_{t}-s_{t}$.

If we start year $t=0$ with debt $b_{0}$ and then the crisis raises the debt to $b_{0}+\Delta$, then the constraint for that year is rewritten as:

$b_{1}=[1+(r-g)]\left(b_{0}+\Delta\right)-s_{0}$.

Assuming that the budget balance is set constant so that $s_{t}=s$ for all $t$ until $t$ $=n$, cumulating the budget constraint gives:

$b_{n}=[1+(r-g)]^{n}\left(b_{0}+\Delta\right)-\frac{[1+(r-g)]^{n}-1}{r-g} s$.

Requiring that the debt returns in year $t=n$ to initial level $b_{0}$, so that $b_{n}=b_{0}$, implies that the constant budget balance $s$ is:

$s=(r-g) b_{0}+(r-g) \frac{[1+(r-g)]^{n}}{[1+(r-g)]^{n}-1} \Delta$.

This is the formula used to draw Figure 1, with $r-g=2$ percent and $\Delta=$ 30percent, for $n$ set at 10 and 25 years. 